\title{
Product Returns: An Opportunity to Shift towards an Access-Based Economy?
}

\author{
Denise Baden (1) and Regina Frei * $*$ (D)
}

check for

updates

Citation: Baden, D.; Frei, R. Product

Returns: An Opportunity to Shift

towards an Access-Based

Economy? Sustainability 2022, 14, 410. https://doi.org/10.3390/su14010410

Academic Editor: Adriana Del Borghi

Received: 9 October 2021

Accepted: 22 December 2021

Published: 31 December 2021

Publisher's Note: MDPI stays neutral with regard to jurisdictional claims in published maps and institutional affiliations.

Copyright: (C) 2021 by the authors. Licensee MDPI, Basel, Switzerland. This article is an open access article distributed under the terms and conditions of the Creative Commons Attribution (CC BY) license (https:// creativecommons.org/licenses/by/ $4.0 /)$.
Southampton Business School, University of Southampton, Southampton SO17 1BJ, UK; d.a.baden@soton.ac.uk * Correspondence: r.frei@soton.ac.uk

\begin{abstract}
With the rise in online purchases, returns polices have become more lenient to maximise sales, leading to increased product returns. This results in considerable costs to businesses due to complex returns systems, and environmental costs due to unnecessary transportation and waste. Unsustainable consumption poses a threat to our environment, and access-based business models whereby products are borrowed/rented rather than purchased have been proposed as a way to align customer needs, business success, and sustainability. Product returns often constitute a form of informal or illegitimate borrowing, as goods are bought with the intention of being returned. In this discussion paper we propose that, instead of being viewed as a threat to business, issues with high product returns could be seen as an opportunity to switch to an access-based model. As product returns escalate, businesses will need to invest substantially in their reverse supply chains. We propose that a more strategic approach might be to leapfrog the costly stage of developing more efficient returns systems, and move straight to formalising product returns as the new normal for those goods that would best suit an access-based model, so that processes are streamlined around borrowing and returning rather than around sales.
\end{abstract}

Keywords: access-based economy; circular economy; product returns; reverse logistics; sharing economy; sustainable consumption

\section{Introduction}

Current consumption and production practices are already exceeding the sustainable limits of ecological systems and are degrading them, creating severe environmental and social risks [1]. It is thus a priority to find ways to meet consumers' material needs without increasing resource consumption. Reducing the environmental unsustainability of our production and consumption systems could be partly achieved by making durable products available through lending, access, and sharing rather than purchase [2-4]. Such models have the potential to facilitate the restructuring of the economy and society towards more sustainable and resilient business and consumption patterns [5,6]. Despite the benefits, few companies have shifted their business models from selling goods to providing access to them. One reason why more firms have not taken up the challenge to switch to more sustainable business models, such as access-based modes of provision, might be that the potential increase in profits is insufficient to counter the risk of switching to a completely new business model [7]. From the business perspective, such a switch would require investment in the development of new skills and processes, as well as additional transaction costs associated with the process of providing, taking back, and cleaning/repairing goods for re-use.

In this paper, we present the argument that most firms are incurring these extra costs anyway due to escalating rates of product returns $[8,9]$. Product return rates have been growing in line with the increase in online purchasing and show no signs of diminishing. We propose that product returns often constitute a form of informal or illegitimate borrowing, as goods are frequently bought with the intention of being returned [10,11]. 
Thus, we are motivated by the following research question: Could accessed-based economy models address product returns? Over the last 20 years, increasing numbers of studies have been devoted to the issue of product returns and reverse logistics in terms of the costs to business, strategic importance, or sustainability issues and waste [12-14]. There is little doubt that increasingly the cost of returns is being seen by businesses as a significant threat to their bottom line [10]. However, if we conceive product returns as a form of informal borrowing, then we can draw a conceptual handshake between product returns and access-based business models. We propose that instead of being seen as a threat, the desire to return products may be seen as an opportunity to switch to more access-based modes of consumption.

In the following sections we draw upon two parallel literatures. The first focuses on access-based consumption, which falls under the umbrella concept of the "sharing economy" and includes related concepts, such as product service systems, libraries of things, rental and leasing models, and sustainable business model innovation. The second stream focuses on issues with product returns, reverse logistics, and closed loop supply chains. At this point, the two literature streams begin to converge around circular economy principles, which include strategies aimed at material recovery as well extending the length and intensity of asset use, and cascading assets through new use cycles [15-17].

\section{Literature Review}

\subsection{Sustainability Challenges}

There is a growing consensus that our current economic systems are unsustainable [18-20]. They are predicated upon constant growth with mass production of goods, putting pressure upon the Earth's resources and leading to issues such as plastic waste, plastic in the food chain, and the likelihood of catastrophic effects on marine and human life if unchecked (ibid). The demand for palm oil, wood, plastics, coconuts, and many other items is depleting our rain forests, increasing the rate of global warming, and leading to loss of biodiversity, air pollution, and impacts on human health [21,22]. There is a number of reasons why the business models of the capitalist world continue to be unsustainable. For instance, ref. [23] asserted that human activities in the last five decades have contributed to the extermination of approximately $60 \%$ of services rendered by the natural ecosystem. This means that sustainability challenges remain a threat to the environment and there is a need for better consumption models. The most obvious is that profits tend to occur from the consumption of goods and services, leading to practices such as designing products that need frequent replacing (planned obsolescence), which is profitable yet wasteful of resources [24].

These are seemingly irreconcilable problems. From the planetary perspective we need to be consuming about a fifth of what we currently consume, yet our economy and business models are predicated upon increasing consumption [18]. In 2019, the media were full of images of floods, barren wastelands decimated by destruction of rainforests, plastic in oceans, and dire warnings of global warming and the need to drastically and immediately reduce our carbon footprint. In 2020, with the outbreak of COVID-19, shops closing, high streets empty, loss of jobs, and a drastic drop in GDP, we were being told to "buy buy buy" as a means to reignite the economy. Individual businesses face similarly contradictory challenges-although they are keen to demonstrate their environmental credentials, their business models typically depend upon maximising sales.

\subsection{Access-Based Models}

A solution that is gaining in popularity is switching to business models based on access, whereby goods are rented, leased, borrowed, or shared rather than owned. For example, in 2011 the sharing economy was named as one of Time Magazine's "Top ten ideas that will change the World," and it was estimated in 2015 that the sharing economy will increase from USD 15 billion in 2015 to USD 335 billion by 2025 [25]. This growth of interest in the sharing economy has been driven by various factors, including the desire to reduce the environmental impacts of resource consumption, the opportunities presented 
by technology and the internet, and users' evolving attitudes towards ownership and socio-economic factors pursuant to better value distribution and more equitable access to resources [26].

Ref. [27] defined the sharing economy as "the socioeconomic system enabled by digital platforms, where businesses or individuals share and exchange access to tangible and intangible assets; and receive a monetary and/or non-monetary compensation in return" (p. 897). In Table 1 we present the various terms that have been classified under the umbrella term of "sharing economy."

Table 1. Sharing economy terminology.

\begin{tabular}{|c|c|}
\hline Sharing economy & $\begin{array}{l}\text { Includes access-based approaches but also schemes where people exchange time, skills, or services } \\
\text { and is defined as "services intended to replace ownership with the sharing and exploitation of } \\
\text { under-used assets, ranging from cars, houses, and parking spaces to pets, books, clothes" [28]. }\end{array}$ \\
\hline $\begin{array}{l}\text { Access-based } \\
\text { economy/access-based } \\
\text { business models }\end{array}$ & $\begin{array}{l}\text { Includes all approaches to people or companies paying to use a product or service without gaining } \\
\text { ownership [29,30]. Typical payment options are fees per use (e.g., Zipcar) or a subscription option } \\
\text { (e.g., Spotify). }\end{array}$ \\
\hline $\begin{array}{l}\text { Collaborative } \\
\text { consumption }\end{array}$ & $\begin{array}{l}\text { Often used interchangeably with "sharing economy" and defined as "peer-to-peer-based activity of } \\
\text { obtaining, giving, or sharing access to goods and services, coordinated through community-based } \\
\text { online services" [6]. }\end{array}$ \\
\hline $\begin{array}{l}\text { Product service system } \\
\text { (PSS): }\end{array}$ & $\begin{array}{l}\text { Ref. [31] distinguished between (i) "product-oriented" PSS, which focuses on selling products with } \\
\text { service contracts attached; (ii) "use-oriented" PSS, where ownership of the product remains with the } \\
\text { provider but the item is lent/rented/leased to the user for a period of time and the product-service } \\
\text { mix relates to use/access to the product but repair, maintenance, and ownership is taken care of by } \\
\text { the provider; and (iii) "result-oriented" PSS, which is focused on providing services rather than } \\
\text { selling products. }\end{array}$ \\
\hline Product stewardship & $\begin{array}{l}\text { The manufacturer and/or retailer remain owners of the product and also take care of maintenance, } \\
\text { repair, replacement, and remanufacture/recycling to produce future product generations [19]. }\end{array}$ \\
\hline Hiring/renting schemes & $\begin{array}{l}\text { Often a short-term arrangement between providers and end-customers, whereby products are used } \\
\text { without transfer of ownership and returned afterwards. These can be B2B, B2C, C2C, etc. This is also } \\
\text { classified by [27] as peer-to-peer rental. }\end{array}$ \\
\hline Leasing schemes & $\begin{array}{l}\text { Like the above, but oriented towards a medium time frame and with the option to gain ownership, } \\
\text { growing in popularity for goods such as electric cars, where innovation is rapid [32]. }\end{array}$ \\
\hline Library models & $\begin{array}{l}\text { Specific libraries that allow users to borrow goods such as tools [33] or toys [34,35] or more general } \\
\text { libraries of things that allow members to borrow items based on per-item fees and/or subscription } \\
\text { models }[36,37] \text {. }\end{array}$ \\
\hline
\end{tabular}

The table above is not comprehensive, and scholars have broken down terms in a number of ways, based on theoretical approaches, business model type, etc. For example, ref. [27] employed a cluster analysis of sharing economy start-ups that identify five key types. Pseudo sharing, usually B2C using pay-per-access fees, is similar to traditional rental but relies on digital platforms. Second is the gig economy, whereby platforms match supply and demand of services based on P2P relationships. P2P rental focuses on products rather than services. The crowd-based economy is similar to the gig economy but with a greater focus on professional providers of services-a kind of hybrid model between crowdsourcing and gig economy. Last is the pooling economy, whereby platforms enable consumers to share, exchange, or rent out products and services to each other, similar to the term "platform economy" preferred by [38].

For the purposes of this paper, the most relevant term is "access-based economy," which includes business models such as library models, renting/hiring models, and "useoriented" PSS.

A related concept is the "access-based economy." Access rather than ownership is the new norm for several sectors such as music, film, cars, etc. For many sectors, this occurs as a result of new technologies and is taken up due to convenience, e.g., Spotify and YouTube. Ref. [39] suggests that it is the younger generation who are predominantly driving 
the access-based economy, preferring access over ownership. Indeed, they may even see ownership as more of a burden than a benefit, especially when ownership comes with responsibility for maintenance (cars, bikes) or clutter (music and film saved on physical recording devices instead of streaming) $[40,41]$.

Much of the literature on concepts such as the sharing economy and access-based economy focuses on peer-to-peer sharing platforms such as Airbnb and services such as Uber, which have been critiqued as a new form of platform capitalism that have done little to address sustainability challenges [42,43]. Yet there is less information on the extent to which concepts such as "access over ownership" are being taken up in the field of product retail [44]. This is a shame, as many of the critiques of the sharing economy in terms of poor working conditions (e.g., Uber) negatively affecting local communities or putting existing businesses out of business (e.g., Airbnb) do not apply to products $[45,46]$. Conversely, the huge potential for environmental benefits, such as less waste and fewer resources needed for manufacturing, and social benefits, such as greater equity in access to resources, accrue mainly to products rather than services [47]. For example, ref. [48] found that drills are typically used only $18 \mathrm{~min}$ per year and emissions from their use are just $2 \%$ of the total emissions, the rest coming from their manufacture, distribution, and disposal. Five drills each rented six times instead of 30 drills being purchased would save an estimated $700 \mathrm{~kg}$ of $\mathrm{CO}_{2}$. The manufacture and transport of goods also gives rise to environmental issues such as deforestation, loss of habitat, loss of biodiversity, pollution, congestion, and toxic waste [49].

Ref. [50] assessed the various kinds of sharing economy business models based on their sustainability credentials, i.e., the extent to which they create net positive social, environmental, and economic value. Most of these are peer to peer, but for this paper we focused on the first of the 13 categories that come under access economy, business to consumer (B2C), which refers to end-consumer access to goods such as clothes (e.g., Rent the Runway), cars (e.g., Zipcar), etc., and whose key sustainability benefits are proposed to be increasing resource efficiency and cost efficiency.

Access-based consumption has also worked well in sectors such as music, which have successfully supplanted ownership with borrowing as people subscribe to services such as Spotify to access music rather than purchasing it [51]. However, access-based consumption has yet to become the norm for more tangible products, and diffusion remains limited. This may be due to tangible value being insufficient, i.e., the cost of renting is too high, or due to the intangible value of ownership in terms of easy access to the products and the esteem benefits of ownership [7]. However, ref. [40] claimed that one way round this is to develop a psychological sense of ownership towards the service, which can substitute for physical ownership. Examples provided include invoking a sense of communal identification among users of the service by facilitating consumer interactions or creating a brand identity that consumers can easily identify with and be proud of.

Several studies refer to the "burdens of ownership" as reasons for consumers to prefer access-based consumption [2,29,30,41,52]. Such burdens include risks (e.g., obsolescence or poor performance) and responsibilities (e.g., repair and maintenance) and issues of storage space. Ref. [53] queried whether "renting is the new buying" by exploring motivations to engage in rental commerce, whereby consumers pay a monthly price for a product that they can then use for the agreed-upon duration. They found that intentions to rent were affected most by perceived economic benefits and that other significant factors were trust, complexity, and levels of knowledge and awareness of rental schemes.

\subsection{Libraries of Things (LoTs)}

All of the above studies of rental/access-based schemes have focused on specific items. However, on a community level, the last decade has seen growth in "Libraries of Things" (LoTs) that extend the library concept to a range of items [37]. A study of six LoTs in the UK in 2018-2019 indicated that they used a mix of membership fees and per-item fees, heavily discounted to attract customers [36]. The kinds of items that are popular are those that are 
expensive, durable, and rarely used, such as carpet cleaners, tools, gardening equipment, sports/holiday equipment, rarely used kitchen items, toys, and games. These LoTs have been successful in terms of meeting sustainability goals, as they minimise consumption and reduce waste and embedded carbon, but have struggled to be economically sustainable, as they tend to be small-scale enterprises that lack marketing clout and resources (ibid). Managers of LoTs agreed that the service they could offer depends very much on scale. Sustainability benefits and convenience of the borrowing service both increase in line with the number of subscribers to the LoT. The more members they have, the more branches they can provide, which reduces transportation costs (sustainability benefits) and convenience for users, thus attracting more members. Similarly, as they increase in size, economies of scale mean they can offer additional products and services (e.g., ability to reserve items), which again enables them to provide a more attractive value proposition.

Although studies of LoTs show the benefits of access-based provision, most LoTs are small social enterprises without the resources to scale up. A particular hurdle to overcome is the lack of consumers' familiarity with the concept and the lack of awareness of the initiatives on offer. This has also been cited as a barrier in numerous other accessbased schemes. Evidence from studies of participants and non-participants in access-based schemes for car leasing and mobile phones, for example [54], shows that familiarity with the concept was the most prevalent reason given for adoption. Conversely, lack of familiarity was a key reason given for non-participation. The next most important theme to emerge was trust in the provider.

\subsection{Barriers to Adoption of Access-Based Business Models}

The brand awareness that large retailers enjoy could help them overcome these trust and awareness barriers, as could their marketing expertise and reach. For example, the success of Spotify as a music distribution model that replaced ownership with access was down in large part to economies of scale that enabled low-cost access-based provision [51]. However, the potential of access-based approaches is yet to be fully realised in other sectors. From the business perspective, it may be the case that the benefits of switching to accessbased business models may not offer sufficiently clear benefits over the current sales model for businesses to want to invest the time and resources to make the switch [7,55].

Leasing and hire models have existed for a while, but are not the norm for most products. As cultural norms of ownership show signs of giving way to norms of access $[39,44,51,53,54]$, is there an opportunity to rebrand an access-based model as the new normal? The financial feasibility of such an alternative is an important consideration, which until now has provided a barrier to fully exploring this as a viable option. Ref. [7] claimed that one of the reasons why access-based schemes have not taken off to date is that, from the business perspective, the extra labour costs involved with renting/leasing (especially in countries with higher salaries) may mean that they are not seen as a more profitable alternative to traditional sales [19]. An access-based business model whereby goods, instead of being sold, are regularly borrowed, requires the development of new skills and processes, raising issues such as how to order, collect, and return goods; logistical issues related to the collection or transportation of goods; who is responsible for the condition of the goods upon return; what to do with damaged goods; etc. Yet high and increasing product returns $[8,9]$ are presenting companies with these issues now anyway, lessening the difference in reality between hiring and selling.

\subsection{Issues of Product Returns}

Recent research indicates a growth in informal, illegitimate borrowing, whereby products are bought for temporary use with every intention of being returned [10]. Companies aspiring to great customer service and positive customer feedback generally have gone out of their way to make it easy to return items. The increase in online buying, in particular, has led companies to allow individuals to return items without indicating any legitimate reason other than "change of mind." This has led to practices such as buying "outfits for the day" 
online that are Instagrammed and then returned. Similarly, ordering a big-screen TV before the championships or children's bikes and BBQs before the summer holidays and returning them afterwards seems to have become socially acceptable. All retailers interviewed by [10] identified such problems, yet struggled to avoid them due to the dilemma between being strict when rejecting improper returns and providing a high standard of customer service. Additionally, research shows that harsher returns policies will negatively impact sales, such that the more lenient and convenient the product returns policies are, the more customers are encouraged to buy, and vice versa [56]. Ref. [57] reported that requiring customers to pay for returns resulted in decreased customer spending with that retailer by $75-100 \%$, whereas customers who were granted free returns increased their spending by $158-457 \%$. At the organisational level, too, policies aimed at maximising sales often increase returns, with many being unaware of the costs incurred by retailers. For example, policies that require a minimum order to qualify for free returns may encourage consumers to purchase goods with an express intention to return them [8].

Costs of returns increase in line with the percentage of items returned, in some cases leaving companies making an actual loss. Conversely, a zero returns rate does not lead to zero costs, as the systems for processing returns still need to be in place. For some product types where returns are exceptionally high, such as fashion and luxury items, returns are at the point where increased sales no longer equate to increased profits [10]. Several cases have been reported whereby the inefficiency or quantity of product returns has led to the cost of the returns being higher than the price of the product in the first instance. Ref. [58] found that the cost of handling returns can be three times as much as the cost of delivering the product. Similarly, a case study of Halfords found that in many cases it was costing more to return items than to manufacture them [59]. A cost calculator developed by [10] found that at a typical returns rate of $20 \%$, the costs of returns is about $12 \%$ of the retail price, whereas at a 35\% rate of returns (typical for online clothing purchases), the cost of returns-related overheads increases to $22.5 \%$. They also found, when applying the cost calculator to a firm that reported $70 \%$ returns rates, that in such cases each item sold was effectively making a loss for the company.

Ref. [10] reported there is typically little oversight of the returns process by senior management, meaning that many retailers are unaware of, or seriously under-estimate, the true costs to the business of product returns [59], some by as much as 150\% [60], especially regarding the extent to which returns policies are being abused [10]. These costs arise for a number of reasons. Returns add to the staff costs required to process them. They also take up physical space in stores or warehouses, thus increasing total inventory and blocking capital, which increases losses due to goods perishing or becoming obsolete. An IMRG review of returns (2020) [9] estimated that $10 \%$ of resalable goods are within the returns process at any one time. The sheer variety of processes involved in returns also creates logistical challenges [10]. In the typical multichannel environment, products may be returned to the store, to a sister brand store, to a drop box, to a parcel shop, or sent via courier or the postal service. Often, the item will travel via a returns distribution centre, where it is assessed and may be sent for recycling, to waste, to charity, to be repaired, returned to the manufacturer, or back to the store, where it may be sold again at full price or discounted, in either case leading to yet more transportation [8]. Furthermore, a considerable proportion of returned products goes to waste, in contradiction with the Corporate Social Responsibility commitments to sustainability and zero landfill that many companies make (ibid). Of particular concern is the lack of transparency regarding what happens to product returns that are sent to "jobbers"-third-party operators that buy product returns in bulk at a discounted price.

Ref. [61] identified a number of particular vulnerabilities due to the ad hoc nature of returns. Costs tend to arise due to mismatched IT systems between the various players in the returns system, which can affect inventory control and financial systems. In addition to the kinds of borrowing behaviour described earlier, there is also evidence of fraud: Ref. [62] reported that in e-commerce, $14 \%$ of returns are fraudulent. This may occur because refunds 
are often given before the returned product has been assessed and checked, leading to fraudulent returns [10]. The complexity of the returns processes also creates opportunities for internal fraud such as theft or collusion with external fraudsters, including failure to scan items. Some problems can be dealt with by having a specified returns desk with trained customer service staff, but this can also reduce customer satisfaction if the desk is far away or they have to queue.

Goods bought online are three times as likely to be returned as goods bought in store [63], and in most areas of online retail, product returns are on an upward curve and show no signs of diminishing $[9,64]$. Most companies have directed their energies towards their forward supply chains to ensure smooth and efficient sales processing and have neglected the reverse supply chain, and it is widely accepted that the efficiency and sophistication of product returns/reverse logistics is vastly inferior to that of sales/forward logistics $[10,59,64]$, which has both cost and environmental implications.

Thus, it makes sense that as the rate of product returns increases, there will be greater incentives for companies to pay more attention to reverse logistics, and a positive relationship has been found between the volume of product returns and the adoption of closed-loop supply chains (CLSCs) $[65,66]$. Ref. [61] concluded from their study of how product returns are managed that the most important principle is that returned goods be seen as assets whose value should be conserved and exploited. This principle is core to CLSCs, which can be defined as consisting of "two supply chains: a forward and a reverse chain; whereby, a recovered product re-enters the traditional forward chain" [67]. CLSCs typically involve repossession of products from end users; reverse logistics to transport items back to where they can be assessed and re-used, repaired, recycled, or remanufactured as appropriate; and, where possible, creating markets for the refurbished products. It can be seen then that CLSC is similar conceptually to access-based provision in terms of its overall aims. Both concepts also fall within circular economy principles. The circular economy has been defined in many different ways [68], but it is understood by many as the idea of keeping resources and materials in circulation for as long as possible, conserving value and minimising waste.

\section{Provocation: From Product Returns to Access-Based Business Models?}

The 2019 consumer returns report "Leveraging Returns Data" cited in [9] indicated that $75 \%$ of supply-chain leaders are acting on this kind of data to look for ways to anticipate customer behaviour, reduce returns rates, and prevent returns fraud. However, this is a big investment with many difficulties. Part of the problem is lack of reliable information. For example, although many firms ask customers to provide reasons for returns, in reality, many customers do not bother, and for those who do, there are reasons to doubt the veracity of the information [10]. Another issue, as stated earlier, is that there is a clear link between sales volume and returns policies that are free and convenient for the customer, yet convenience to the customer comes at a cost to the business. On the environmental front, outsourcing product returns to third parties such as "jobbers" results in lack of transparency or knowledge about how many products are going to landfill [8]. Further, policies that aim to fully capture and extend product lifecycles are often in tension with commercial drivers, leading to contentious and environmentally harmful practices such as planned obsolescence [69].

In this discussion paper, we propose that, instead of being viewed as a threat to business, issues with high product returns could be seen as an opportunity to switch to an access-based model. As product returns escalate, businesses will need to invest substantially in their reverse supply chains, which is likely to be a costly and complex process. We ask whether it makes sense, therefore, to leapfrog the costly stage of developing more efficient returns systems, and move straight to formalising product returns as the new normal for those goods that would best suit an access-based model, so that processes are streamlined around borrowing and returning rather than around sales. 


\subsection{Horizon Scanning}

Horizon scanning by monitoring trends and likely changes in the environment is central to managing business risk [70]. A key risk to businesses is climate change, with the governor of the Bank of England in 2019 warning that firms that ignore climate change will go bankrupt [71]. Concerns about climate change, resource scarcity, pollution, loss of biodiversity, water shortages, etc., are likely to result in increased regulation and financial pressures (via taxes, supply-chain pressures, and incentives) for businesses to switch to more sustainable business models. There are also consumer pressures: A poll in 2019 of 2000 respondents reported that half expressed concern about the environmental and social impact of fast fashion and took this into account when buying clothing [72]. A third also considered sustainability issues relating to household items. Similarly, a report on the UK ethical consumer market indicated that ethical consumption has increased four-fold since 1999 , in contrast to average household expenditure, which has grown by just $2 \%$ [73]. These factors all suggest that pressures will grow rather than diminish for companies to reduce their environmental impacts.

One of the "burdens of ownership" reported in the literature is the storage of goods, and there are additional trends evident of minimalism, as exemplified by the popularity of books, blogs, and programmes on decluttering and space saving [74,75]. In addition to cultural shifts against ownership [39,44,51,53,54], there are also signs of a reduced social acceptability of high consumption due to climate change [76,77]. As sea levels rise due to global warming [78] reducing habitable land, trends related to space saving and anticonsumption are likely to grow. Therefore, companies whose business strategies centre around maximising sales face risks of product returns eating into profit margins, or even leading to net losses, as well as risks due to the likely emergence/increase of sustainable policies and mindsets.

\subsection{Examples of Access-Based Business Models}

There is growing familiarity, awareness, and adoption of access-based modes of consumption. Some companies faced with high returns are already exploring such options. For example, Ikea are researching how to develop a product-stewardship approach based on circular economy ideas to transform the way in which we think about ownership [79]. This has involved working with the Furniture Reuse Project so customers can return old furniture when they buy new items. The idea is to build a relationship with their customers to supply furnishings that they can take back, update, and refresh any time. Ikea own the furniture and take it back to reuse or recycle to minimise waste and increase resource use efficiency. A study examining initiatives at Ikea aimed at capturing value from second-hand objects through buy-back and take-back schemes and increased offerings of after-sales parts emphasised the importance of customer convenience in success and the relevance of product design, resource allocation, and availability of spare parts as critical factors in the recovery of value. Early inspection and separation of products was also important to minimise unnecessary transportation [80].

Similarly, access-based business models, both peer to peer and B2C, are growing in the fashion sector. GlobalData estimated that the budding market for online clothing rentals is set to grow to USD 2.5 billion by 2023 [81]. In 2019, the fashion retail store Urban Outfitters began a new clothes-rental service called Nuuly and expect it to have 50,000 subscribers and generate an income of USD 50 million in its first year (ibid).

There is also a variety of sharing and access-based schemes in the field of transport, such as numerous bike-sharing schemes, car-pooling, and peer-to-peer car sharing $[5,29]$. In the B2C realm, Zipcar is one of the best-known examples. Zipcar is a vehicle-sharing firm operating in 384 cities in the UK, Canada, Turkey, Iceland, Andorra, and the USA [82]. As of 2020, Zipcar had over one million members, operated more than 1600 vehicles, had lowered carbon emission by 1.6 billon lbs per year, and had reduced the need for more than 415,00 personally owned cars [83]. In addition, Zipcar has witnessed a consistent annual growth of $100 \%+$ over the years. Through the access-based model, they aim to 
create better neighbourhoods by cutting carbon emissions, reducing vehicular traffic, and promoting multi-modal travel. They operate an access-based subscription vehicle-sharing model where members can reserve, use, and return cars.

Zipcar sells its offerings on cost and convenience as much as the sustainability implications. For instance, whereas owning a personal car requires pricey monthly payments or a huge outright payment, Zipcar offers a low rental cost per trip. In addition, prices are inclusive of insurance cover compared to expensive monthly or annual insurance payments for a personally owned car. Moreover, Zipcar covers car maintenance, refuelling, and parking spaces across cities, whereas individuals would have to pay for those services if they owned a personal car.

The above examples indicate business models related to access over ownership for specific product types, yet there is untapped potential for access-based models to be adopted by a broader range of retailers and for a greater range of durable items that consumers require for a limited time only [84]. Opportunistic returns, which is another term for wardrobing or illicit renting of products, accounted for $11 \%$ of returns in the USA in 2017 [85], illustrating the scale of opportunities for access business models. Ref. [86] estimated that returns abuse, which includes wardrobing as well as other strategies, such as ordering an additional item to qualify for free shipping, with the intention to return the item afterwards, accounts for 32\% of returns and is worth USD 24 billion annually in the USA. In the UK, this is estimated to cost GBP 1.5 billion, and $43 \%$ of 16 - to 24 -year-olds and $39 \%$ of 25- to 34-year-olds admitted to engage in wardrobing [87]. Indeed, it is one of the biggest challenges that retailers currently face [88], with [89] suggesting working with the wardrobing customers rather than against them by offering a menu of price/refund pairs. In other words, retailers are advised to offer access-based solutions.

\section{Conclusions and Further Research Directions}

This paper discusses the need for access-based economy models as a solution to product returns. By explicating and demonstrating why access-based economy models might address product returns, this paper makes a useful contribution to the circular economy and products-returns literature. This discussion paper, being arguably among the few to invoke this debate, provides a useful foundation for future research. Circular economy principles, focusing on resource reuse, are widely promoted by organisations such as the Ellen McArthur Foundation and have influenced policy and innovation in some of the world's largest economies $[17,90]$. Progress towards a more circular economy depends on creating greater public and business understanding and engagement with access-based schemes [17], and better understanding of how they can deliver an attractive customer experience [7], because to date, there has been insufficient attention paid to innovations in terms of customer engagement [91]. This requires business models for sustainable innovation [92]. These are defined by [93] as "innovations that create significant positive and/or significantly reduced negative impacts for the environment and/or society, through changes in the way the organisation and its value-network create, deliver value and capture value (i.e., create economic value) or change their value propositions" (p. 44) [39], for example, suggested that businesses should focus on the idea of being solution providers rather than on trying to maximise sales.

With forecasts that up to three billion people will join the global middle class by 2050 [7], finding ways to meet consumers' material needs while consuming fewer resources has become an urgent priority. This challenge requires, among others, a shift away from business models that encourage high consumption and deplete natural capital. Business models that meet consumer needs through product access rather than ownership can offer value to customers in terms of convenience, saving space and costs, and being more sustainable.

Many high-street businesses have shut down as they fail to meet customer needs, but could they perhaps have been saved by switching to a more innovative business model? Mothercare, an international brand, closed its retail outlets in the UK in 2019. Yet if it were 
Mother Share, for example, rather than Mothercare, might the store have provided greater value to its customers, who, due to the nature of the products, will only need them for a limited period of time? More general department stores are also struggling to survive. Might they offer better value if one could buy membership, for example, to the fashion, sports, kitchen, or games department for oneself, one's family, or as a present, rather than specific items that have a high likelihood of being returned?

Future research could usefully explore which packages of product, service, payment models, access, and information are sufficiently pleasing to customers that they will be persuaded to switch to access over ownership as the new normal. Research into how to develop processes around renting/borrowing and returning on a large scale that are as efficient as those relating to sales is also required to achieve the cost savings required for commercial feasibility. Companies struggling with high product returns and who expect to see the rate of returns continue to increase may find that switching to an access-based model that formally presents customers with a package that suits their needs makes both commercial and environmental sense. In the short term, it may be feasible for specific products that have high returns such as fashion, but in the longer term, switching more generally to access over ownership for the majority of items may help to future proof businesses against anti-consumption trends and low-carbon policies that are likely to emerge as the environmental impacts of overconsumption become increasingly evident. Lastly, future research should consider providing empirical evidence on the performance of access-based economy models, especially within retail, since existing studies have only provided anecdotal findings.

Author Contributions: D.B. and R.F. contributed to all aspects of this work. All authors have read and agreed to the published version of the manuscript.

Funding: This research received no external funding.

Conflicts of Interest: The authors declare no conflict of interest.

\section{References}

1. Bengtsson, M.; Alfredsson, E.; Cohen, M.; Lorek, S.; Schroeder, P. Transforming systems of consumption and production for achieving the sustainable development goals: Moving beyond efficiency. Sustain. Sci. 2018, 3, 1533-1547. [CrossRef]

2. Belk, R. You are what you can access: Sharing and collaborative consumption online. J. Bus. Res. 2014, 67, 1595-1600. [CrossRef]

3. Eckhardt, G.M.; Bardhi, F. The sharing economy isn't about sharing at all. Harv. Bus. Rev. 2015, $28,2015$.

4. Lebel, L.; Lorek, S. Enabling sustainable production-consumption systems. Annu. Rev. Environ. Resour. 2008, 33, 241-275. [CrossRef]

5. Cohen, B.; Kietzmann, J. Ride on! Mobility business models for the sharing economy. Organ. Environ. 2014, 27, 279-296. [CrossRef]

6. Hamari, J.; Sjöklint, M.; Ukkonen, A. The sharing economy: Why people participate in collaborative consumption. J. Assoc. Inf. Sci. Technol. 2016, 67, 2047-2059. [CrossRef]

7. Tukker, A. Product services for a resource-efficient and circular economy-A review. J. Clean. Prod. 2015, 97, 76-91. [CrossRef]

8. Frei, R.; Jack, L.; Krzyzaniak, S. Sustainable reverse supply chains and circular economy in multichannel retail returns. Bus. Strategy Environ. 2020, 29, 1925-1940. [CrossRef]

9. IMRG. IMRG Returns Review-2020; Metapack: London, UK, 2020.

10. Jack, L.; Frei, R.; Krzyzaniak, S.-A.C. Buy Online, Return to Store: The Challenges and Opportunities of Product Returns in a Multichannel Environment. Efficient Consumer Response. 2019. Available online: https://www.ecrloss.com/research/buyonline-return-in-store (accessed on 22 December 2021).

11. Wachter, K.; Vitell, S.J.; Shelton, R.K.; Park, K. Exploring consumer orientation toward returns: Unethical dimensions. Bus. Ethics: A Eur. Rev. 2012, 21, 115-128. [CrossRef]

12. Bernon, M.; Tjahjono, B.; Ripanti, E.F. Aligning retail reverse logistics practice with circular economy values: An exploratory framework. Prod. Plan. Control 2018, 29, 483-497. [CrossRef]

13. Hjort, K.; Hellström, D.; Karlsson, S.; Oghazi, P. Typology of practices for managing consumer returns in internet retailing. Int. J. Phys. Distrib. Logist. Manag. 2019, 49,767-790. [CrossRef]

14. Röllecke, F.J.; Huchzermeier, A.; Schröder, D. Returning customers: The hidden strategic opportunity of returns management. Calif. Manag. Rev. 2018, 60, 176-203. [CrossRef]

15. Esposito, M.; Tse, T.; Soufani, K. Is the circular economy a new fast-expanding market? Thunderbird Int. Bus. Rev. 2017, 59, 9-14. [CrossRef] 
16. Sposato, P.; Preka, R.; Cappellaro, F.; Cutaia, L. Sharing economy and circular economy. How technology and collaborative consumption innovations boost closing the loop strategies. Environ. Eng. Manag. J. 2017, 16, 1797-1806. [CrossRef]

17. Winans, K.; Kendall, A.; Deng, H. The history and current applications of the circular economy concept. Renew. Sustain. Energy Rev. 2017, 68, 825-833. [CrossRef]

18. Jackson, T. Prosperity without Growth: Foundations for the Economy of Tomorrow; Routledge: Abingdon, UK, 2016.

19. Millstone, C. Frugal Value: Designing Business for a Crowded Planet; Routledge: Abingdon, UK, 2017.

20. Reichel, A.; De Schoenmakere, M.; Gillabel, J.; Martin, J.; Hoogeveen, Y. Circular economy in Europe: Developing the knowledge base. Eur. Environ. Agency Rep. 2016, 2, 2016.

21. Folke, C.; Österblom, H.; Jouffray, J.-B.; Lambin, E.F.; Adger, W.N.; Scheffer, M.; Crona, B.I.; Nyström, M.; Levin, S.; Carpenter, S.R.; et al. Transnational corporations and the challenge of biosphere stewardship. Nat. Ecol. Evol. 2019, 3, 1396-1403. [CrossRef]

22. Pye, O. Commodifying sustainability: Development, nature and politics in the palm oil industry. World Dev. 2019, 121, 218-228. [CrossRef]

23. Khattak, S.I.; Ahmad, M.; Khan, Z.U.; Khan, A. Exploring the impact of innovation, renewable energy consumption, and income on CO2 emissions: New evidence from the BRICS economies. Environ. Sci. Pollut. Res. 2020, 27, 13866-13881. [CrossRef]

24. Porritt, J. Capitalism as if the World Matters; Routledge: London, UK, 2012.

25. PwC, U. The Sharing Economy-Sizing the Revenue Opportunity. 2015. Available online: www.pwc.co.uk/issues/megatrends/ collisions/sharingeconomy/the-sharing-economy-sizing-the-revenue-opportunity.html (accessed on 17 July 2020).

26. Cheng, M. Sharing economy: A review and agenda for future research. Int. J. Hosp. Manag. 2016, 57, 60-70. [CrossRef]

27. Sanasi, S.; Ghezzi, A.; Cavallo, A.; Rangone, A. Making sense of the sharing economy: A business model innovation perspective. Technol. Anal. Strateg. Manag. 2020, 32, 895-909. [CrossRef]

28. Vaskelainen, T.; Münzel, K. The effect of institutional logics on business model development in the sharing economy: The case of German carsharing services. Acad. Manag. Discov. 2018, 4, 273-293. [CrossRef]

29. Bardhi, F.; Eckhardt, G.M. Access-based consumption: The case of car sharing. J. Consum. Res. 2012, 39, 881-898. [CrossRef]

30. Lawson, J.S.; Gleim, M.R.; Perren, R.; Hwang, J. Freedom from ownership: An exploration of access-based consumption. J. Bus. Res. 2016, 69, 2615-2623. [CrossRef]

31. Tukker, A. Eight types of product-service system: Eight ways to sustainability? Experiences from SusProNet. Bus. Strategy Environ. 2004, 13, 246-260. [CrossRef]

32. Huang, Y.; Qian, L.; Soopramanien, D.; Tyfield, D. Buy, lease, or share? Consumer preferences for innovative business models in the market for electric vehicles. Technol. Forecast. Soc. Change 2021, 166, 120639. [CrossRef]

33. Söderholm, J. Borrowing and Lending Tools: The Materiality of x-Lending Libraries. Ph.D. Thesis, Högskolan i Borås, Borås, Sweden, 2018.

34. Moore, J.E. A History of Toy Lending Libraries in the United States since 1935. Master's Thesis, Kent State University, Kent, OH, USA, 1995. Unpublished.

35. Ozanne, K.L.; Ballantine, P.W. Sharing as a form of anti-consumption? An examination of toy library users. J. Consum. Behav. 2010, 9, 485-498. [CrossRef]

36. Baden, D.; Peattie, K.; Adekunle, O. Sustainable Business Model Innovation: The Potential of Libraries of Things; EURAM: Lisbon, Portugal, 2019.

37. Robison, M.; Shedd, L. Audio Recorders to Zucchini Seeds: Building a Library of Things; ABC-CLIO: Santa Barbara, CA, USA, 2017.

38. Kenney, M.; Zysman, J. The Rise of the Platform Economy. Issues Sci. Technol. 2016, 32, 61.

39. Denning, S. An economy of access is opening for business: Five strategies for success. Strategy Leadersh. 2014, 42, 14-21. [CrossRef]

40. Fritze, M.P.; Marchand, A.; Eisingerich, A.B.; Benkenstein, M. Access-based services as substitutes for material possessions: The role of psychological ownership. J. Serv. Res. 2020, 23, 368-385. [CrossRef]

41. Schaefers, T.; Lawson, S.J.; Kukar-Kinney, M. How the burdens of ownership promote consumer usage of access-based services. Mark. Lett. 2016, 27, 569-577. [CrossRef]

42. Foramitti, J.; Varvarousis, A.; Kallis, G. Transition within a transition: How cooperative platforms want to change the sharing economy. Sustain. Sci. 2020, 15, 1185-1197. [CrossRef]

43. Frenken, K.; Schor, J. Putting the sharing economy into perspective. In A Research Agenda for Sustainable Consumption Governance; Edward Elgar Publishing: Cheltenham, UK, 2019.

44. Mont, O.; Palgan, Y.V.; Bradley, K.; Zvolska, L. A decade of the sharing economy: Concepts, users, business and governance perspectives. J. Clean. Prod. 2020, 269, 122215. [CrossRef]

45. Martin, C.J. The sharing economy: A pathway to sustainability or a nightmarish form of neoliberal capitalism? Ecol. Econ. 2016, 121, 149-159. [CrossRef]

46. Vith, S.; Oberg, A.; Höllerer, M.A.; Meyer, R.E. Envisioning the 'sharing city': Governance strategies for the sharing economy. J. Bus. Ethics 2019, 159, 1023-1046. [CrossRef]

47. Ciulli, F.; Kolk, A. Incumbents and business model innovation for the sharing economy: Implications for sustainability. J. Clean. Prod. 2019, 214, 995-1010. [CrossRef]

48. Skjelvik, J.M.; Erlandsen, A.M.; Haavardsholm, O. Environmental Impacts and Potential of the Sharing Economy; Nordic Council of Ministers: Copenhagen, Denmark, 2017. 
49. Castellani, V.; Beylot, A.; Sala, S. Environmental impacts of household consumption in Europe: Comparing process-based LCA and environmentally extended input-output analysis. J. Clean. Prod. 2019, 240, 117966. [CrossRef]

50. Laukkanen, M.; Tura, N. The potential of sharing economy business models for sustainable value creation. J. Clean. Prod. 2020, 253, 120004. [CrossRef]

51. Sun, H. Case study-Spotify. In Digital Revolution Tamed; Springer: Berlin/Heidelberg, Germany, 2019; pp. 135-170.

52. Moeller, S.; Wittkowski, K. The burdens of ownership: Reasons for preferring renting. Manag. Serv. Qual. 2010, $20,176-191$. [CrossRef]

53. Fota, A.; Wagner, K.; Schramm-Klein, H. Is renting the new buying? A quantitative investigation of the determinants of the rental-commerce intention. Int. Rev. Retail Distrib. Consum. Res. 2019, 29, 582-599. [CrossRef]

54. Poppelaars, F.; Bakker, C.; Van Engelen, J. Does access trump ownership? Exploring consumer acceptance of access-based consumption in the case of smartphones. Sustainability 2018, 10, 2133. [CrossRef]

55. Besch, K. Product-service systems for office furniture: Barriers and opportunities on the European market. J. Clean. Prod. 2005, 13, 1083-1094. [CrossRef]

56. KPMG. Annual Retail Survey. 2018. Available online: https://assets.kpmg/content/dam/kpmg/uk/pdf/2018/01/kpmgannual-retail-survey-2018.pdf (accessed on 25 July 2020).

57. Bower, A.B.; Maxham, J.G. Return shipping policies of online retailers: Normative assumptions and the long-term consequences of fee and free returns. J. Mark. 2012, 76, 110-124. [CrossRef]

58. KPMG. Annual Retail Survey. 2017. Available online: https://assets.kpmg/content/dam/kpmg/uk/pdf/2017/02/retail-survey2017.pdf (accessed on 22 December 2021).

59. Cullen, J.; Tsamenyi, M.; Bernon, M.; Gorst, J. Reverse logistics in the UK retail sector: A case study of the role of management accounting in driving organisational change. Manag. Account. Res. 2013, 24, 212-227. [CrossRef]

60. The Retail Equation. Return Rate Miscalculations Impact Retail Chains Nationwide Calculating Your Real Return Rate. 2015. Available online: https://apprissretail.com/resource/white-paper-return-rate-miscalculations-impact-retail-chains-nationwide/ (accessed on 10 October 2018).

61. Frei, R.; Jack, L.; Brown, S. Product returns: A growing problem for business, society and environment. Int. J. Oper. Prod. Manag. 2020, 40, 1613-1621. [CrossRef]

62. Panda, S. Two sides to every story ... return logistics and return frauds. Reverse Logist. Mag. 2018, 90, 18-20.

63. Lawrence, B. The Ecommerce Returns Problem (and How to Tackle It). 2020. Available online: https://inviqa.com/blog/ ecommerce-returns-problem-and-how-tackle-it (accessed on 25 July 2020).

64. Bernon, M.; Cullen, J.; Gors, J. Online retail returns management: Integration within an omni-channel distribution context. Int. J. Phys. Distrib. Logist. Manag. 2016, 46, 584-605. [CrossRef]

65. Guide, V.D.R., Jr.; Van Wassenhove, L.N. OR FORUM-The evolution of closed-loop supply chain research. Oper. Res. 2009, 57, 10-18. [CrossRef]

66. Shaharudin, M.R.; Tan, K.C.; Kannan, V.; Zailani, S. The mediating effects of product returns on the relationship between green capabilities and closed-loop supply chain adoption. J. Clean. Prod. 2019, 211, 233-246. [CrossRef]

67. Wells, P.; Seitz, M. Business models and closed-loop supply chains: A typology. Supply Chain. Manag. Int. J. 2005, 10, $249-251$. [CrossRef]

68. Kirchherr, J.; Reike, D.; Hekkert, M. Conceptualizing the circular economy: An analysis of 114 definitions. Resour. Conserv. Recycl. 2017, 127, 221-232. [CrossRef]

69. Ertz, M.; Leblanc-Proulx, S.; Sarigöllü, E.; Morin, V. Made to break? A taxonomy of business models on product lifetime extension. J. Clean. Prod. 2019, 234, 867-880. [CrossRef]

70. Brown, D. Horizon scanning and the business environment-The implications for risk management. BT Technol. J. 2007, 25, 208-214. [CrossRef]

71. Carrington, D. Firms ignoring climate crisis will go bankrupt, says Mark Carney. The Guardian. 2019. Available online: https:/ / www.theguardian.com/environment/2019/oct/13/firms-ignoring-climate-crisis-bankrupt-mark-carney-bankengland-governor (accessed on 25 July 2020).

72. Knight, R. Millions of Britons Determined to Live More Sustainably by Buying Secondhand, New Poll Claims. The Independent. 2019. Available online: https://www.independent.co.uk/news/uk/second-hand-clothes-vintage-sustainability-environmentfashion-a9210846.html (accessed on 18 July 2020).

73. Ethical Consumer, Coop. Twenty Years of Ethical Consumerism. Ethical Consumerism Report. Available online: https: / /www.cooperative.coop/twenty-years-of-ethical-consumerism (accessed on 22 December 2021).

74. Biana, H.T. Philosophizing about Clutter: Marie Kondo's The Life-Changing Magic of Tidying Up. Cult. Int. J. Philos. Cult. Axiolog. 2020, 17, 73-86. [CrossRef]

75. Mangold, S.; Zschau, T. In Search of the "Good Life": The Appeal of the Tiny House Lifestyle in the USA. Soc. Sci. 2019, 8, 26. [CrossRef]

76. Joanes, T.; Gwozdz, W.; Klöckner, C.A. Reducing personal clothing consumption: A cross-cultural validation of the comprehensive action determination model. J. Environ. Psychol. 2020, 71, 101396. [CrossRef]

77. Lee, M.S.W.; Egea, J.M.O.; De Frutos, N.G. Anti-consumption beyond boundaries: From niche topic to global phenomena. Psychol. Mark. 2020, 37, 171-176. [CrossRef] 
78. IPCC. Global Warming of $1.5^{\circ} \mathrm{C}$; Intergovernmental Panel on Climate Change: Geneva, Switzerland, 2018.

79. Elf, P. Supporting Sustainable Lifestyle Change: An Evaluation of IKEA's Live Lagom Project. Ph.D. Thesis, University of Surrey, Guildford, UK, 2020.

80. Malmgren, K.; Larsson, K.M. Reverse Logistics in the Transition towards Circular Economy-A Case Study of Customer Returns at IKEA. Master's Thesis, Chalmers University of Technology, Göteborg, Sweden, 2020.

81. BBC. Urban Outfitters Inc to Rent out Clothing. 2019. Available online: https://www.bbc.co.uk/news/business-48360379 (accessed on 21 May 2019).

82. Movmi. Carsharing Market \& Growth Analysis. 2019. Available online: https://movmi.net/carsharing-market-growth-2019/ (accessed on 17 July 2020).

83. Zipcar. What Is Zipcar. 2020. Available online: https:/ / www.zipcar.com/about (accessed on 17 July 2020).

84. Timoumi, A.; Coughlan, A.T. Wardrobing: Is It Really All That Bad? Working Paper. 2013. Available online: https://marketing. wharton.upenn.edu/wp-content/uploads/2016/10/Paper-Coughlan-Anne-01-17-2013.pdf (accessed on 16 December 2021).

85. Altug, M.S.; Aydinliyim, T.; Jain, A. Managing opportunistic consumer returns in retail operations. Manag. Sci. 2021, 67, 5660-5678. [CrossRef]

86. Hearne, J. Serial Returners Beware: Retailers Attempt to Tackle the Problem of 'Wardrobing'. Irish Examiner, 5 March 2020. 2020. Available online: https:/ / www.irishexaminer.com/opinion/columnists/arid-30985934.html (accessed on 16 December 2021).

87. Reitblat, M. Returns Abuse: A \$24 Billion Problem. TotalRetail. 2020. Available online: https://www.mytotalretail.com/article/ returns-abuse-a-24-billion-problem/ (accessed on 16 December 2021).

88. Petrikaite, V. A search model of costly product returns. Int. J. Ind. Organ. 2018, 58, 236-251. [CrossRef]

89. Shang, G.; Ghosh, B.P.; Galbreth, M.R. Optimal retail return policies with wardrobing. Prod. Oper. Manag. 2017, 26 , 1315-1332. [CrossRef]

90. Hobson, K.; Lynch, N. Diversifying and de-growing the circular economy: Radical social transformation in a resource-scarce world. Futures 2016, 82, 15-25. [CrossRef]

91. Prieto-Sandoval, V.; Jaca, C.; Ormazabal, M. Towards a consensus on the circular economy. J. Clean. Prod. 2018, 179, 605-615. [CrossRef]

92. Boons, F.; Lüdeke-Freund, F. Business models for sustainable innovation: State-of-the-art and steps towards a research agenda. J. Clean. Prod. 2013, 45, 9-19. [CrossRef]

93. Bocken, M.N.; Short, S.W.; Rana, P.; Evans, S. A literature and practice review to develop sustainable business model archetypes. J. Clean. Prod. 2014, 65, 42-56. [CrossRef] 